\title{
Research on the Integration of Maker Education and Practical Teaching of Automation Major
}

\author{
Guihua Yang* \\ Guilin University of Technology \\ Guangxi Guilin, China
}

\author{
Huaihui $\mathrm{Li}$ \\ Guilin University of Technology \\ Guangxi Guilin, China
}

\begin{abstract}
Maker education combined with professional education is an important way to effectively improve college students' innovation and entrepreneurship ability. In order to stimulate students' interest in learning and creativity, this paper proposes that the practical teaching of automation major should be student-centered, based on the advantages of the major itself, and fully integrate the educational thoughts of makers in the aspects of practical teaching ideas, teaching contents, teaching methods and teacher construction. This practical teaching mode has been implemented in the teaching of automation major in our university. It has achieved remarkable results in improving the quality of talent cultivation, creating a practical teaching platform and promoting the development of teachers.
\end{abstract}

Keywords-Maker Education; Automation Major; Practical Teaching; Teaching Effect

\section{INTRODUCTION}

Since the development of technology, innovative talents have been required to have the ability of critical thinking and problem solving, creativity and innovation, communication and cooperation[1]. As a new education model, maker education has the educational concept of "open innovation and exploration experience", takes "learning through creation" as the main mode, and pays more attention to the cultivation of talents' innovation and creation ability[2]. This is consistent with the current goal of cultivating professional education talents in universities. The organic integration and mutual support of professional education and maker education can effectively improve the quality of talent training.

\section{ANALysis On the Teaching Status of Practical COURSES OF AUTOMATION MAJOR}

\section{A. Problems Existing in Practical Teaching}

At present, most of the practical courses in the college such as experiment and training are still based on the traditional teaching mode. Most of them run the mode of didactic teaching. In a fixed time and place, a teacher determines the contents and steps of the experiment, and then students follow the same pattern as what the teacher does, which leads students lacking of independent mind, critical consciousness an innovative spirit. The practice project is formulated by the

[supported project]: The 13th five-year plan of Education Science in guangxi "The construction and application of maker education ecosystem in guangxi university of science and engineering"(NO.2017C377); Special research topic on the theory and practice of university innovation and entrepreneurship education in 2018(NO. GUT2018cy8); Comprehensive teaching reform of $\mathrm{C}$ language program. teacher, and students are divided into groups freely. The division of labor and responsibilities in a group are not clearly enough, which causes one person to do all of the works. In the end, the team consciousness becomes not strong, the learning initiative is not enough, and the learning effect turns not ideal.

\section{B. Status Analysis}

The author argues that the reasons for the poor effectiveness of practical teaching are as follows:

\section{1) The inadequacy of cultivation mechanism}

At present, the teaching mode of undergraduate courses in most universities is still teacher-centered injection mode, and the teaching method mainly consists of teaching and questioning. Students are under a passive state of learning, with low participation and low interest in learning. Particularly, in the experimental training courses, the experimental content is single that leads the students easy to copy each other. Due to the lack of effective innovation, ability training mechanism, competition means, students can not effectively stimulate their innovation consciousness with poor pressure. They can not put more energy into innovation activities, resulting in widespread problems that students' participation in practical activities is poor; innovation ability can not be exercised and so on.

2) The inadequacy of cultivation mechanism

Due to the limited resources of the subject experiment platform, many experiments and practical links that need to be carried out cannot be completed normally. In addition, the opening time of the laboratory is fixed, and the laboratory equipment cannot be freely used. What's more, the lack of innovation in the laboratory management system also seriously restricts the further realization of students' innovative thinking.

\section{3) The inadequacy of the innovation atmosphere}

Interest is the best teacher of learning; a good atmosphere can stimulate interest in learning. A considerable number of students muddle along in their studying, and only consider innovation and entrepreneurship when they are really facing graduation and have difficulty in employment. As a result, they find that they seriously lack relevant professional competence. In addition, there are also some problems such as the deficiency in teachers' own innovation ability, the insufficient of the type of teaching materials, and the low degree of integration between teaching and learning.

This traditional education mode designed by constructivism focuses on one-way knowledge transmission, which is difficult to stimulate students' interest in learning, resulting in a serious 
and competition, and effectively strengthen the training of engineering practice and innovation ability. The idea of integrating the innovation of maker education is to insist on taking students as the main body, strengthen and perfect the practical teaching links to specialty, and construct the model of maker education in colleges and universities that is oriented by "learning, doing and creating". Based on giving full play to the advantages of automation major, it focuses on reforming the education concept, teaching content, teaching method and construction of teaching staff of automation major, and strengthening the learning goal of cultivating students' high-level thinking ability in the design of practical teaching activities. Interdisciplinary learning content to integrate 3D printing technology and open-source hardware technology; It integrates research, project-based learning and experiential innovation learning activities, O2O learning space design, and the construction of interdisciplinary and cross-field teaching staff[3].

\section{THE INNOVATION OF MAKER EDUCATION IN PRACTICAL} TEACHING

\section{A. Practice teaching philosophy}

The teaching concept is the basic attitude and concept that people hold towards in teaching activities, which guides the establishment and development of specific teaching activities ${ }^{[4]}$. The combination of maker concept and automation professional education based on students' learning interests uses digital tools, advocates creation and encourages sharing. Maker education aims at cultivating students' teamwork ability, interdisciplinary problem-solving ability and innovation ability. It has six characteristics: discipline integration, encouraging to practice, opening creation, enthusiasm for sharing, adhering to the profession and serving the society[5]. It is consistent with the objective and objective of talent training in colleges and universities in the current "new engineering education and training plan". The organic integration can support each other and effectively promote the improvement of the quality of talent training in engineering technology.

The traditional practical teaching philosophy mainly emphasizes the cultivation of students' practical ability and aims at verifying the learning content of theoretical courses. Students usually practice according to the designed experimental content and steps, and passively accept it[6]. However, the change of the practical teaching concept has added many new factors besides practical ability for practical teaching. First, according to the open nature of maker education, a new concept of practical teaching is proposed, which is to build a school-based talent training community and a new school-running mechanism of the council, integrate and optimize educational resources, and comprehensively enhances school-running vitality. Secondly, with the ability training as the core, the top optimization design of electromagnet integration excellent innovative talent training program and curriculum system, reform of teaching methods, effectively solve the mainline of the curriculum system unclear, poor connection, innovative practice links; Thirdly, it is necessary to build a multilevel electromagnet comprehensive practice teaching system that is coordinated inside and outside the school and in the class, to promote learning through interaction

\section{B. Practice teaching content}

The practical teaching contents of automation major integrated with the concept of maker education are mainly reflected in the design of practical projects. A good maker project has eight elements: relevance, complexity, novelty, high investment, relevance, sharing, availability and time[1]. Adhering to the characteristics of maker education, the learning environment for makers was constructed under the guidance of the concept of maker education, and curriculum experiments were designed in this environment, and experiments, internship outline and guidance books were compiled. The practical projects designed should reflect:

(1)The practical projects are problem-oriented and meet the needs of the society as the premise, that is, relevance;

(2) Practical projects often involve multiple subjects, pay attention to the cross-use of knowledge, to ensure the systematization and integrity of professional education itself, that is, complexity;

(3) Focusing on the innovation and cutting-edge features of practical projects, is conducive to the play of students' creativity, that is, novelty;

(4) Practice project content strongly attract the attention of students, students are willing to invest time and energy high, that is, high investment;

(5) The whole project is arranged in a compact manner. Attention should be paid to the correlation between courses and experiments;

(6) The process of practice training cannot be separated from teamwork. Students and teachers from different majors participate together to form an interdisciplinary research and practice model;

(7) Ensuring the availability of experimental materials, equipment and resource tools, as well as the freedom of the opening time of the experimental center, that is, the availability and sufficient time.

\section{Practical teaching methods}

The practice teaching integrated with the concept of maker education adopts the teaching method of "teacher-oriented-student-oriented", which not only attaches importance to giving full play to the leading role of teachers in the teaching process, but also fully reflects the dominant position of students in the learning process[7]. Under this teaching method, teachers play the roles of leader, organizer and facilitator, arrange students' learning progress according to teaching requirements, release learning tasks, upload learning resources, submit homework and answer questions online through online learning platform, communication and discussion platform and sharing platform. As well as the non-face-to-face synchronous or asynchronous communication discussion and student work-sharing and other organizations a series of learning activities. In some comprehensive and innovative projects, students are encouraged to form a project team across grades and majors, 
independently research, design, test and manufacture project products, and the instructor are responsible for guidance, supervision and evaluation. Practical teaching activities of automation major can be divided into three modes according to the teaching content. The following shows the design of practical project activities according to different links.

\section{(1) Discursive practical projects}

Students "learning": (1)Relevant professional theoretical and practical knowledge.

Teacher "leading": providing subject $\rightarrow$ Providing tools and resources $\rightarrow$ enlightening $\rightarrow$ reviewing.

Students "do": Receiving task $\rightarrow$ examining the literature $\rightarrow$ group discussion $\rightarrow$ reporting.

Ability training: critical thinking ability; communication skills; cooperation ability.

\section{(2)Task-based practice projects}

Students "learning": (1)Relevant professional theoretical and practical knowledge; (2) 3D printing manufacturing technology, Welding skills, open-source hardware skills and other basic skills knowledge;(3)General process approach for project production.

Teacher "leading": providing subject $\rightarrow$ enlightening $\rightarrow$ guiding $\rightarrow$ evaluation and deepening.

Students "do": Receiving task $\rightarrow$ determining solution $\rightarrow$ prototype design $\rightarrow$ results show.

Ability training: critical thinking ability; communication skills; cooperation ability; practical ability.

\section{(3)Experiential creative projects}

Students "learning": (1)Relevant professional theoretical and practical knowledge; (2)3D printing manufacturing technology, Welding skills, open-source hardware skills and other basic skills knowledge; (3) General process approach for project production; (4)Knowledge of innovation and entrepreneurship; (5)Acquisition of New skills in the process of creation.

Teacher "leading": providing subject $\rightarrow$ enlightening $\rightarrow$ organizing and monitoring $\rightarrow$ guiding and solving questions $\rightarrow$ evaluating and reflecting.

Students "do": perceiving task $\rightarrow$ discovering problem $\rightarrow$ propose creative solutions $\rightarrow$ schematic design $\rightarrow$ prototype design $\rightarrow$ sharing and communicating $\rightarrow$ reflection and improvement $\rightarrow$ achieving the goal.

Ability training: critical thinking ability; communication skills; cooperation ability; practical ability; innovation and entrepreneurship ability

This teaching design transforms the single transmission of knowledge into the design of teaching situations, the passive acceptance of students into active participation, and the knowledge transfer between teaching and learning into knowledge endogenous and ability training. It is an embodied teaching design of "integrating teaching with practice".

\section{Teacher team construction}

The introduction of maker education in colleges and universities should start from changing the concept of automation professional teachers, and strengthen and enhance the level and ability of teachers. First, change the relationship between teachers and students, more inclined to transform the relationship between teachers and students to master-apprentice and the relationship of this kind of education and guest cognitive apprenticeship, not just focus on the skills of apprentice acquisition, but in the face of the complex scene, to combine its own conceptual and factual knowledge to deep understanding and analysis of problems, to produce creative solutions, make up for the lack of theory and practice of students face the real scene to contact.[8]Teachers should not only provide students with a good demonstration, guidance and scaffolding but also guide students to express their own ideas, reflect on their own learning behavior and explore a model to solve the problem. Secondly, the role of teachers should be changed. Teachers should not only teach students the necessary professional knowledge but also help them grow in professional skills and practical fields. Therefore, maker teachers should integrate the mentoring relationship of craftsmen into traditional classrooms, and the role of teachers should be changed from simple to diversify. Again, changes in the structure of teachers, and education focus on cultivating students' interdisciplinary and multidisciplinary integration of comprehensive knowledge and skills acquisition, so the knowledge structure of teachers' team should not be a single individual teachers, and teachers of different subjects should be by school and enterprise expert teacher team, able to undertake to the student interdisciplinary, innovative thinking, hands-on practice and develop all-round innovation entrepreneurship. However, professional teachers are mainly responsible for the whole practice project, playing a leading role in the learning environment and personnel management, while other teachers can be responsible for different contents from different perspectives.

\section{THE EFFECT OF INTEGRATING MAKER EDUCATION INTO PROFESSIONAL PRACTICE TEACHING}

The reform and implementation of the practical teaching mode integrating maker education in the teaching of automation major in our university have obvious effects on the steady improvement of talent training quality. In the past three years, students have obtained more than 20 scientific research projects at various levels, including 5 national innovation and entrepreneurship training programs and 12 autonomous region level projects. Students participated in various schools, Guamanian autonomous region and national discipline competitions and won more than 40 prizes above the provincial level, published 15 papers and granted 4 patents. Among them, I won the national special prize, the first prize and the second prize of "Siemens cup" industrial automation challenge. 2 second prizes in national "challenge cup" scientific and technological works competition for college students; National college students "free-scale" cup intelligent car competition 
Guamanian, host and participate in the complete project "engine developed embedded intelligent controller" and "four compound rubber unit series development" Guamanian scientific and technological progress second prize.

\section{CONCLUSION}

Practical teaching in engineering education and training system is very important. It is an important link to colleges and universities to train students' practical ability, engineering consciousness and innovation and entrepreneurship ability. Through the automation practice teaching system reform, it will be a guest in education concept into the practice teaching link, inspire the students' interest and creativity, built a core to adapt to the ability and engineering innovation ability, the campus practice for the two wings with off-campus practice, step by step progressive type of three-dimensional practical teaching system, realize the students' self-learning ability, innovation thinking ability, the training objectives of engineering design ability, communication and coordination ability.

\section{REFERENCES}

[1] The NMC Horizon Report 2016 who Education Edition [EB/OU].http://www.nmc.org/publication /nmc-horizon-report-2016higher-education-edition/.

[2] Yang Xianmin, Li Jihong. Value potential and controversy of maker Education [J]. Modern distance education research. 2015(2): pp.23-24. (In Chinese)

[3] GUI Liang, Jin Yue, Zhao Weijun, Guo Ting, Zhang Jun. Application of $3 \mathrm{D}$ printing technology in maker practical teaching [J]. Experimental technology and management. Vol.33 No.10 Oct.2016,pp.181-184.(In Chinese)

[4] Duan Zhuzhang. Analysis on the connotation and characteristics of teaching philosophy [J]. Education guide.2011(11):pp.15-18. (In Chinese)

[5] Zhu Zhiting, Luo Liang. From maker movement to make education: cultivating a culture of mass innovation [J]. Audio-visual education research, 2015 (7): pp. 5-13. (In Chinese)

[6] Jia Jie, Integration of maker education and engineering training in institutions of higher learning [J]. Experimental technology and management. Vol.32 No.12, 2015, pp.30-32+35. (In Chinese)

[7] Sun Yusheng, Cheng Yanan, Zhu Lijun. Research on the construction of university teaching model based on MOOC [J]. Journal of distance education.2015(5): pp.65-71. (In Chinese)

[8] Huang Hailong. Construction of maker education teaching system and exploration of teaching implementation [J]. Chinese modern educational equipment.2019(7): pp.110-113. (In Chinese) 